\title{
G1/S-Specific Cyclin-D1b
}

National Cancer Institute

\section{Source}

National Cancer Institute. G1/S-Specific Cyclin-D1b. NCI Thesaurus. Code C118477.

G1/S-specific cyclin-D1b is encoded by the human CCND1 gene. This protein may play a role in the promotion of tumor cell invasiveness and anchorage-independent growth. 